Tema: $1^{\circ}$ Workshop de tratamentos de superfícies de ligas resistentes à corrosão

\title{
CORROSION RESISTANCE OF AISI 316L STAINLESS STEEL NITRIDED BY THREE DIFFERENT PLASMA ASSISTED TECHNIQUES*
}

\author{
Darina Manova ${ }^{1}$ \\ Stephan Mändl2 \\ Sonia P. Brüh/ ${ }^{3}$ \\ Lisandro Escalada 4 \\ Silvia Simison ${ }^{5}$
}

\begin{abstract}
Plasma assisted surface modification methods have been used to nitride stainless steels in order to enhance hardness and therefore the lifetime of industrial components. Nevertheless, the corrosion resistance is not always preserved since it is very sensitive to the process parameters, either in implantation or in thermochemical diffusion techniques. AISI 316L stainless steel was plasma nitrided using three different techniques: Low Energy Ion Implantation (LEII), Plasma Immersion Implantation (PI3) and conventional DC pulsed plasma nitriding (DCPN). For each method several parameters were tested and some of them were selected to achieve the so called S phase of about $3 \mu \mathrm{m}$ thickness and no nitrides precipitation. The nitrided layer was characterized with OM and SEM. Hardness was assessed on the surface with Vickers indenter and $25 \mathrm{~g}$ load. XRD was performed to characterize the $S$ phase and to detect other phases if present and electrochemical corrosion tests were carried out in $3.5 \% \mathrm{NaCl}$ solution. Although the $\mathrm{S}$ phase thickness in the three groups of samples was comparable, hardness was not and neither was the corrosion resistance. The PI3 samples were the hardest with the best performance in corrosion experiments, resulting in a higher breakdown potential and lower currents.
\end{abstract}

Keywords: Plasma nitriding; Stainless steel; Corrosion; Implantation.

\footnotetext{
Ph.D., Senior Researcher, Leibniz-Institut für Oberflächenmodifizierung (IOM), Leipzig, Germany. Ph.D., Senior Researcher, Leibniz-Institut für Oberflächenmodifizierung (IOM), Leipzig, Germany. 3Ph. D, Full Professor, Surface Engineering Group, Universidad Tecnológica Nacional (UTNFRCU), Ing., Concepción del Uruguay, Argentina.

4 Ph. D, Full Professor, Corrosion Division, INTEMA, Facultad de Ingeniería, Universidad Nacional de Mar del Plata, Mar del Plata, Argentina.

5 Ph.D. Student, Corrosion Division, INTEMA, Facultad de Ingeniería, Universidad Nacional de Mar del Plata, Mar del Plata, Argentina,
}

\footnotetext{
* Technical contribution to the $1^{\text {st }}$ Workshop on surface treatments of corrosion resistant alloys, July $21^{\text {st }}-25^{\text {th }}$, 2014, São Paulo, SP, Brazil.
} 


\section{INTRODUCTION}

Austenitic stainless steels has an extended use in different industries due to its good corrosion resistance [1,2]. The fields of application are wide from tanks and heat exchangers to prosthesis or instrumental devices. Nevertheless, there are several situations in which their poor tribological properties seem to be a problem. The plasma nitriding of these steels can overcome their limitations, because it is possible to form nitrogen rich layers of high hardness [3-6]. On the other hand, in order to keep a high corrosion resistance it is necessary to avoid the precipitation of $\mathrm{CrN}$ that usually occurs above $450^{\circ} \mathrm{C}$ [7-11]. During the past twenty years different plasma assisted nitriding techniques had been established and some of them started to commercialize in an industrial scale [12-16].

The corrosion behaviour of the layers obtained by these methods is still an issue for the design of the process. The principal advantages of these treatments are the use of lower temperatures, a better control of surface structure, no sometimes, a shorter duration compared to the traditional gas nitriding. Three of the most popular methods are plasma immersion ion implantation, low energy ion implantation, and direct current pulsed plasma nitriding (or ion nitriding). There is a lot of information in the literature, overlooking these different processes and characterizing the nitride layer obtained combining different variables and setups.

In this work three different plasma assisted techniques were used to nitride AISI 316L surface with the aim of improving wear behaviour without affecting corrosion resistance, therefore low temperatures were used. Plasma Immersion lon Implantation (PI3), Low Energy Ion Implantation (LEII) and conventional DC Pulsed Glow Discharge Nitriding (DCPPN) were carried out to modify the near surface of AISI 316L stainless steel.

\section{MATERIALS AND METHODS}

The samples for this work were prepared from a $25 \mathrm{~mm}$ diameter rod bar of austenitic stainless steel AISI316L. The bar was sliced to obtain discs of $6 \mathrm{~mm}$ thickness. The samples were grounded with SiC paper and then mirror polished prior to nitride them. PI3 and LEIl were performed in Leibniz Institute for Surface Modification (IOM), in Leipzig, Germany. DC pulsed plasma nitriding was carried out in UTN, Faculty of Concepción del Uruguay, in Argentina.

The nitriding treatments were carried out using selected process parameters to assure a nitrogen supersaturated expanded austenite phase, called $S$ phase or $\gamma \mathrm{N}$, without $\mathrm{Fe}$ or $\mathrm{Cr}$ nitrides precipitation $[3,6]$.

Process parameters are as follow: PI3 experiments were performed with $10 \mathrm{kV}$ bias and $15 \mathrm{~ms}$ pulse during 1 hour treatment, at a temperature of $430^{\circ} \mathrm{C}$ and $0.84 \mathrm{~Pa}$ pressure. LEll experiments used an ECR Ion source, ion of $0.8 \mathrm{keV}$ energy, temperature was kept in $430^{\circ} \mathrm{C}$, and implantation was pulsed using $30 \%$ duty cycle, during $1 \mathrm{~h}$. Finally, DCPPN was carried out in a $22 \% \mathrm{~N}_{2}-\mathrm{H}_{2}$ atmosphere, current density was kept at $1.05 \mathrm{~mA} / \mathrm{cm}^{2}$, temperature at $410^{\circ} \mathrm{C}$ and the treatment duration was set in $6 \mathrm{~h}$, with $2 \mathrm{~h}$ previous sputtering in $\mathrm{Ar}-\mathrm{H}_{2}$ atmosphere.

The phases obtained were investigated with X-ray diffraction (XRD) in Bragg Brentano geometry using CuK $\alpha$ radiation. The thickness of the nitrided layer was measured by the observation of polished cross sections, etched with Marble reagent, to reveal the microstructure.

\footnotetext{
* Technical contribution to the $1^{\text {st }}$ Workshop on surface treatments of corrosion resistant alloys, July $21^{\text {st }}-25^{\text {th }}$, 2014, São Paulo, SP, Brazil.
} 
The wear tests were carried out in a dry sliding situation using a pin on disk selfdesigned machine. Normal load was fixed in $4 \mathrm{~N}$, tangential velocity in $10 \mathrm{~cm} / \mathrm{s}$, a $\mathrm{Si}_{3} \mathrm{~N}_{4}$ ball was used as counterpart, radius was $7 \mathrm{~mm}$ and the total sliding distance was $700 \mathrm{~m}$. The wear track was measured using a surface roughness meter acting as profilometer and from the mean value of six cross sections; the volume loss of the sample was calculated, assuming cylindrical symmetry.

Electrochemical tests were carried out at room temperature and atmospheric pressure, in a three electrode cell. The tested sample was slightly polished to eliminate any air formed oxide, and was used as the working electrode in each test. As auxiliary and reference, a platinum wire and a saturated calomel were used. The tested area was restricted pressing an O-ring to the sample surface, giving an area of $0.41 \mathrm{~cm}^{2}$. The electrolyte was $3.5 \mathrm{wt} \% \mathrm{NaCl}$ water solution saturated with air. To evaluate the localized corrosion resistance, cyclic potentiodynamic polarization experiments were carried out with a sweep rate of $1 \mathrm{mV} / \mathrm{s}$. The reversal of the potential was done at a fixed, arbitrary chosen current density of $200 \mu \mathrm{A} / \mathrm{cm}^{2}$. This potential was called $\mathrm{E}_{200}$.

\section{RESULTS AND DISCUSSION}

\subsection{Microstructure and Hardness}

After the nitriding processes some samples were cut and mounted to observe the nitrided layer, while on others hardness was measured on the surface and XRD analysis was carried out. Table 1 shows the average nitride layer thickness and average hardness in each case. In this work, the processes variables were controlled in order to have comparable thicknesses between the different nitriding techniques. In this way, a better comparison between the layers can be done.

Table 1. Hardness, thickness and (111) peak position of the nitrided layers

\begin{tabular}{lccc}
\hline SAMPLE & HV 0,05 & $\gamma_{\mathbf{N}}$ width $[\boldsymbol{\mu m}]$ & XRD (111) $\mathbf{2 \theta}$ \\
\hline LEII & $525 \pm 5$ & 3.8 & 40.3 \\
\hline PI3 & $846 \pm 7$ & 4.0 & 39.4 \\
\hline DCPPN & $590 \pm 10$ & 6.5 & 41.5 \\
\hline
\end{tabular}

Figure 1 shows the XRD diffraction patterns. All the samples show the particular shift of the peaks to lower angle, due to the presence of the expanded austenite. No other species, like $\mathrm{CrN}$, are present in the nitrided samples. As the thickness is similar, we attribute the difference in the peak shift to a larger lattice expansion due to the mean ion energy in each process. As the two implantation methods (PI3 and LEII) are more energetic they produce the major lattice expansion and the highest shift to lower angles is observed, especially in the (111) peak. In the LEll samples a signal form the austenite could also be detected, because the layer is the thinnest.

\footnotetext{
* Technical contribution to the $1^{\text {st }}$ Workshop on surface treatments of corrosion resistant alloys, July $21^{\text {st }}-25^{\text {th }}, 2014$, São Paulo, SP, Brazil.
} 


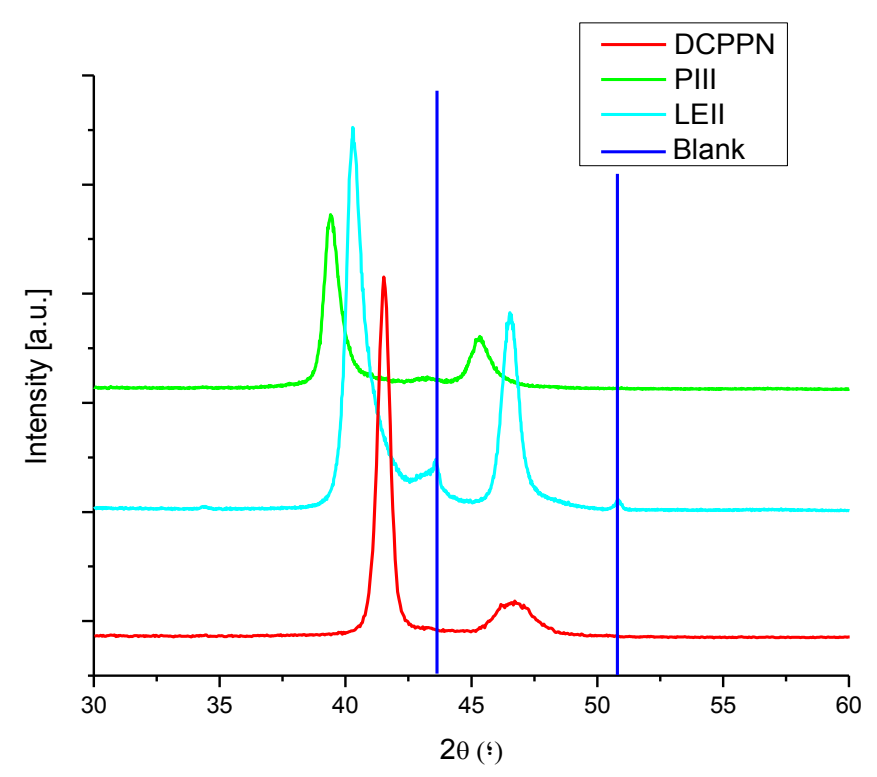

Figure 1. XRD diffraction patterns of the three nitrided samples with vertical black lines indicating the (111) and (200) peaks positions for the untreated steel.

\subsection{Wear}

Regarding pin on disk experiments all the treated samples had a better behaviour than the untreated material but the behaviour of the PI3 sample was remarkable since it had the minor volume loss with a nitrided layer only $4 \mu \mathrm{m}$ thickness. As expected, wear loss was also in relation to hardness. It was verified that in all cases the wear track depth was not bigger than the nitrided layer thickness. Results are presented together with corrosion data in Table 2.

\subsection{Corrosion}

The result of the polarization tests are plotted in Figure 2. The passive current density is lower and the reversal potential is higher for all the nitrided samples compared to the untreated specimen. The best localized corrosion resistance compared to the blank is shown by the PIII and the DCPPN samples reaching $E_{200}$ values of around $1 \mathrm{~V}$ and $0.9 \mathrm{~V}\left(\mathrm{E}_{200}\right.$ blank $\left.=0.3 \mathrm{~V}\right)$.

Table 2. Wear and corrosion data compared to untreated steel (blank)

\begin{tabular}{|c|c|c|}
\hline SAMPLE & $\begin{array}{c}\text { Volume } \\
\text { loss }\left[\mathrm{mm}^{3}\right]\end{array}$ & $\begin{array}{c}\text { Corrosion }\left(E_{200}\right) \\
[V])\end{array}$ \\
\hline LEII & 19.0 & 0.51 \\
\hline $\mathrm{PI3}$ & 12.2 & 0.90 \\
\hline DCPPN & 31.2 & 1.00 \\
\hline Blank & 44.6 & 0.34 \\
\hline
\end{tabular}

* Technical contribution to the $1^{\text {st }}$ Workshop on surface treatments of corrosion resistant alloys, July $21^{\text {st }}-25^{\text {th }}, 2014$, São Paulo, SP, Brazil. 

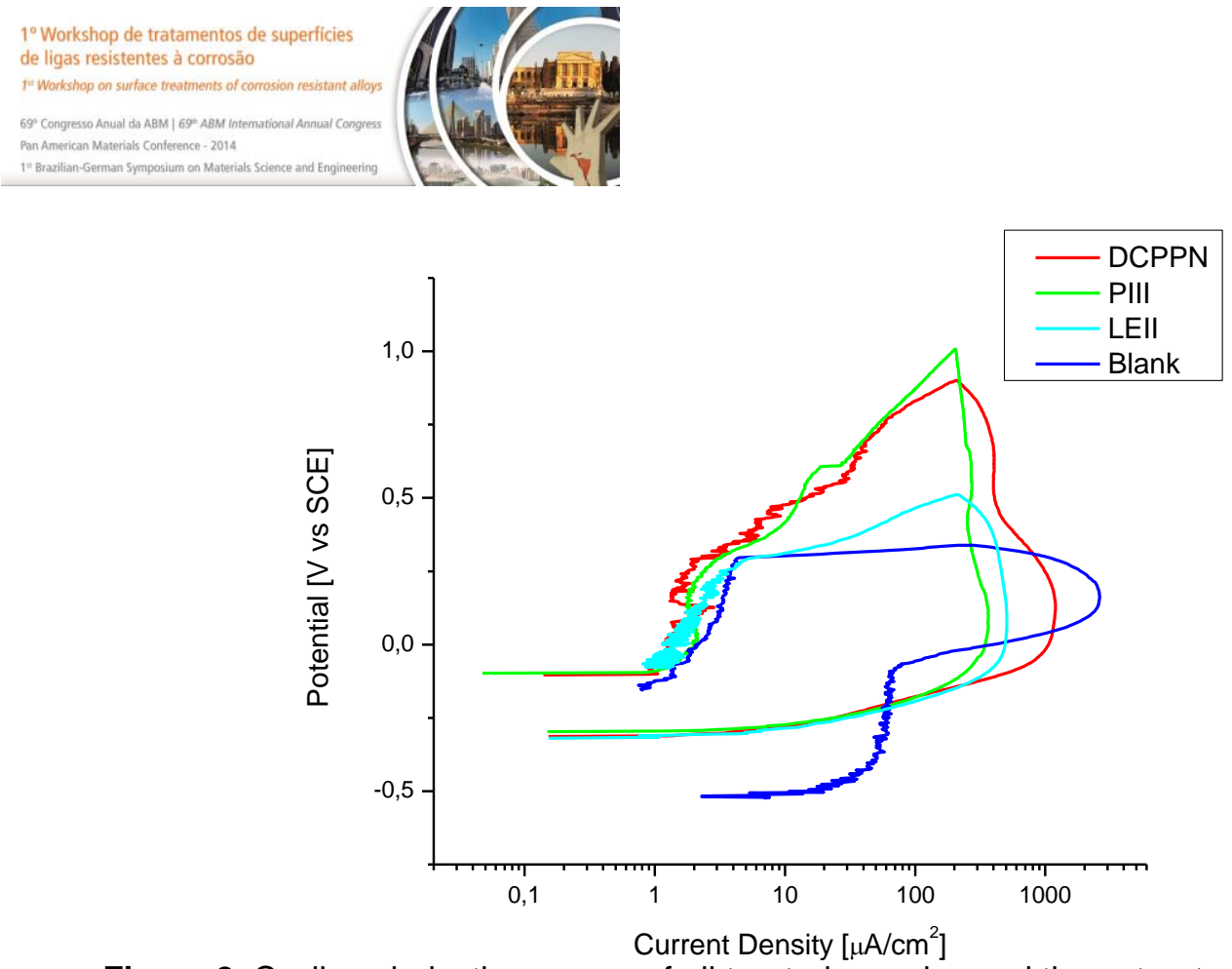

Figure 2. Cyclic polarization curves of all treated samples and the untreated steel (blank)

From optical microscopic observation it was determined that the corrosion morphology is similar for all the nitrided processes: black spots surrounded by shallow corrosion products (Figure 3 ).

These black spots are related to the presence of inclusions in the base alloy. The properties of the passivating films are being under study in order to go further in an explanation of the observed behavior.

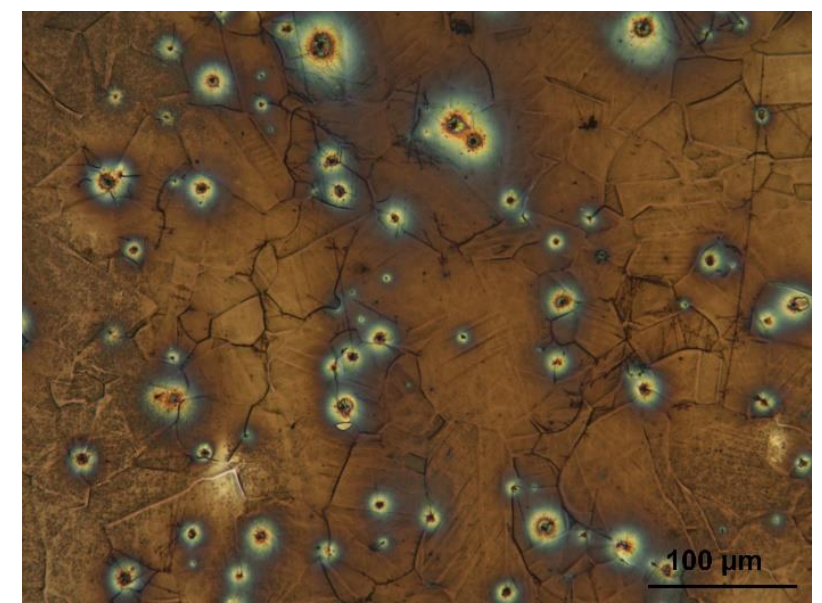

Figure 3. Optic micrograph of the nitrided steel surface after the corrosion test

\section{CONCLUSION}

From the wear and corrosion tests, the best behaviour corresponds to the "high density" layer of PI3, $4 \mu \mathrm{m}$ and almost $850 \mathrm{HV}$ in hardness. With DCPNN thicker layers can be obtained with more treatment time, then hardness and wear resistance will be increased, even sustaining corrosion resistance. But the advantage of the implantation is the short duration of the nitriding treatment to obtain the expanded austenite phase and a high nitrogen concentration in a not very thick layer. It remains still an issue if DCPNN can make such a nitrided layer applying other process parameters than usual.

* Technical contribution to the $1^{\text {st }}$ Workshop on surface treatments of corrosion resistant alloys, July $21^{\text {st }}-25^{\text {th }}$, 2014, São Paulo, SP, Brazil. 
The corrosion attack morphology is similar in all the nitrided samples. More work has to be done in order to go deeper in the basics mechanisms behind this behaviour.

\section{Aknowledgements}

This work was carried out in the frame of a Bi-National Cooperation project founded by BMBF (Germany)-MINCYT (Argentina Nr. Al/09/03). This work was also founded by ANPCYT -Argentina, PICT 1807.

\section{REFERÊNCIAS}

1 Novak CJ, Handbook of Stainless Steels. New York: McGraw-Hill; 1977 (Ch. 4).

2 Lo KH, Shek CH, Lai JKL. Recent developments in stainless steels. Materials Science and Engineering R: Reports. 2009; R65: 39-104.

3 Bell T. Current Status of Supersaturated Surface Egineered S-phase Materials. Key Engineering Materials. 2008; 373-374: 289-295.

4 Dong H, Qi PY, Li XY, Llewellyn RJ. Improving the erosion-corrosion resistance of AISI 316 austenitic stainless steel by low-temperature plasma surface alloying with $\mathrm{N}$ and $\mathrm{C}$ Materials Science and Engineering A. 2006; 431: 137-145.

5 Stinville JC, Villechaise P, Templier C, Rivière JP, Drouet M. Plasma nitriding of 316L austenitic stainless steel: Experimental investigation of fatigue life and surface evolution Surface and Coatings Technology. 2010; 204: 1947-1951.

6 Mingolo N, Tschiptschin AP and Pinedo CE. On the formation of expanded austenite during plasma nitriding of an AISI 316L austenitic stainless steel. Surface and Coatings Technology. 2006; 201: 4215-4218.

7 Borgioli F, Fossati A, Galvanetto E, Bacci T. Glow-discharge nitriding of AISI 316L austenitic stainless steel: influence of treatment temperature. Surface and Coatings Technology. 2005; 200: 2474-2480.

8 Gontijo LC, Machado R, Kuri SE, Casteletti LC, Nascente PAP. Study of the S phase formed on plasma-nitrided AISI 316L stainless steel. Thin Solid Films. 2006; 515: 10931096.

9 Fossati A, Borgioli F, Galvanetto E and Bacci T. Corrosion resistance properties of glowdischarge nitrided AISI 316L austenitic stainless steel in $\mathrm{NaCl}$ solutions. Corrosion Science. 2006; 48: 1513-1527.

10 Gil L, Brühl S, Jiménez L, León O, Guevara R and Staia MH. Corrosion performance of the plasma nitrided 316L stainless steel. Surface and Coatings Technology. 2006; 201: 4424-4429.

$11 \mathrm{Li} \mathrm{CX}$ and Bell T. Corrosion properties of active screen plasma nitrided 316 austenitic stainless steel. Corrosion Science. 2004; 46: 1527-1547.

12 Singh V, Marchev K, Cooper CV, Meletis El. Intensified plasma-assisted nitriding of AISI 316L stainless steel. Surface and Coatings Technology. 2002; 160: 249-258.

13 Figueroa CA, Alvarez F. New pathways in plasma nitriding of metal alloys. Surface and Coatings Technology. 2005; 200: 498-501.

14 Escalada L, Lutz J, Mändl S, Manova D, Neumann H and Simison S. Corrosion properties of stainless steel 316L after energetic nitrogen insertion. Surface and Coatings Technology. 2012; 211: 76-79.

15 Wei R, Vajo JJ, Matossian JN, Wilbur PJ, Davis JA, Williamson DL and Collins GA. A comparative study of beam ion implantation, plasma ion implantation and nitriding of AISI 304 stainless steel. Surface and Coatings Technology. 1996; 83: 235-242.

16 Blawert C, Kalvelage H, Mordike BL, Collins GA, Short KT, Jirásková Y and Schneeweiss $\mathrm{O}$. Nitrogen and carbon expanded austenite produced by PI3. Surface and Coatings Technology. 2001; 136: 181-187

\footnotetext{
* Technical contribution to the $1^{\text {st }}$ Workshop on surface treatments of corrosion resistant alloys, July $21^{\text {st }}-25^{\text {th }}, 2014$, São Paulo, SP, Brazil.
} 